\title{
THE EFFECT OF CR AND DAR ON ROA ON COAL MINING SUB SECTOR COMPANIES LISTED ON BEI
}

\author{
Hasmirati \\ Management, Ichsan University Gorontalo, Gorontalo \\ Email: asmhy392@gmail.com
}

Received: 2021-09-06; Received in revised from: 2021-09-13; Accepted: 2021-10-18

\begin{abstract}
Abstrak
Penelitian ini bertujuan untuk mengetahui dan menganalisis seberapa besar pengaruh Return Current Ratio (X1) dan Debt to Total Assets Ratio (X2) baik secara simultan maupun parsial terhadap Return on Assets. Penelitian adalah penelitian kuantitatif, dengan menggunakan analisis rasio. Metode analisis menggunakan regresi linier berganda. Hasil penelitian menunjukkan bahwa Current Ratio (X1) dan Debt to Total Assets Ratio (X2) secara simultan tidak berpengaruh signifikan terhadap Return on Assets pada perusahaan sub sektor Pertambangan Batubara yang terdaftar di Bursa Efek Indonesia sebesar 0,057. Current Ratio (X1) secara parsial berpengaruh signifikan terhadap Return on Assets hal ini karena Ttabel 2,024 < Thitung 2,369. Debt to Total Assets Ratio (X2) secara parsial berpengaruh signifikan terhadap Return on Assets hal ini karena Ttabel 2,024 < Thitung 2,347.
\end{abstract}

Kata kunci: $C R, D A R, R O A$

\begin{abstract}
This study aims to determine and analyze how much influence the Return Current Ratio (X1) and Debt to Total Assets Ratio (X2) both simultaneously and partially have on Return On Assets. This research is a quantitative study, using ratio analysis. The analysis method uses multiple linear regression. The results showed that the Current Ratio (X1) and Debt to Total Assets Ratio (X2) simultaneously did not have a significant effect on the Return on Assets of the Coal Mining subsector companies listed on the Indonesia Stock Exchange of 0.057. Current Ratio (X1) secara parsial berpengaruh signifikan terhadap Return on Assets hal ini karena Ttabel 2,024 < Thitung 2,369 . Debt to Total Assets Ratio (X2) secara parsial berpengaruh signifikan terhadap Return on Assets hal ini karena Ttabel 2,024 < Thitung 2,347.
\end{abstract}

Keywords: $C R, D A R$, dan ROA

\section{Introduction}

The current economic situation has had many impacts or changes in the national economy, especially considering the increasing competition in the business world. The establishment of the company aims to increase the value of the company so that the company can provide benefits to the owners or shareholders and the company. The company is said to have good performance if it is able to generate profits and vice versa is said to have poor performance if it is not able to generate profits.

Every company has a maximum profit goal, which means that profits must be as expected [1]. Therefore, use financial ratios to measure the company's profit level. Return on Assets (ROA) is an analytical technique commonly used by company leaders to measure the effectiveness of the company's overall operations. Return on assets (ROA) aims to be able to measure the company's ability with all funds invested in assets that generate profits in the company's operations [2].

Several factors that affect Return on Assets are Current Ratio and Debt to Total Assets Ratio. [3] states that the Current Ratio has an effect on Return on Assets, the higher the Current Ratio level of 
a company, the ability to generate profits will also tend to increase. [4] shows that Debt to Total Assets will affect Return on Assets. The higher the ratio, the more debt financing. The increasing use of debt causes an increase in company profits.

This research was conducted on a coal mining sub-sector company. Where the Coal Sector experienced a decline in revenue of $-0.66 \%$ due to external factors from importing countries that fell quite sharply (www.batubara.com) in China so far, the country experienced tremendous pollution, and people acknowledged again that reducing coal burning means reducing global warming emissions. A study last year explained that about 1.6 million people die each year from air pollution. This is equivalent to $17 \%$ of all deaths in China, so China began to reduce coal consumption. It can be seen from the data that the data shows that the supply of coal to the Zhulian country has fallen by $11 \%$ to 2,016 million tons. During this period, coal imports also fell by $35 \%$, or about 56 million tons, while China's domestic production fell by 194 million tons compared to the same period last year.

\subsection{Literatur Review}

\section{Current Ratio (CR)}

The current ratio is a ratio used to measure the company's ability to pay short-term obligations or debts that must be paid immediately when billing as a whole [1]. If the company can meet its shortterm obligations on time, it can be said that the company is liquid.

\section{Debt to Total Assets Ratio (DAR)}

The Debt to Total Asset Ratio is the debt ratio used to measure the ratio between total debt and total assets [5]. In other words, how much money is provided by the company's assets or how much impact the company's debt has on asset management. Meanwhile, [6] stated Debt to Total Asset Ratio This is also known as the ratio, which represents the company's debt ratio, which is calculated by dividing the ratio of total debt by total assets.

\section{Return on Assets (ROA)}

To measure the effectiveness of the company's operations, leaders usually use return on assets analysis. Return on Assets (ROA) itself is a form of profitability ratio, which is designed to be able to measure the company's ability with all funds invested in the company's operating assets that generate profits [2].

The return on assets is a ratio that shows the results of the total assets used by the company [1]. Return of assets is not only for company owners, but also for outsiders.

\section{Method}

The research method used in this research is descriptive method. Descriptive research is research that aims to explain the existence of phenomena by using numbers to explain the characteristics of individuals or groups. This study assesses the nature of the situation [7]. The population of this study are all companies that are included in the coal mining sub-industry. The data source used for this research was obtained from the official website of the Indonesian stock exchange, namely www.idx.co.id. in the form of published company financial statements. This study aims to test whether the current ratio and debt to total assets affect the return on assets. For this reason, multiple linear regression analysis techniques will be used. It can be described as the following Figure 1. 


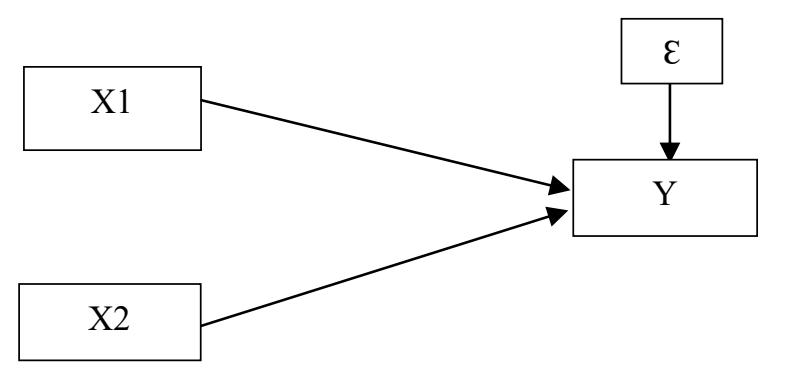

Figure 1. Multiple Regression Structure

\section{Results and Discussion}

Tabel 1. Multiple Regression Test

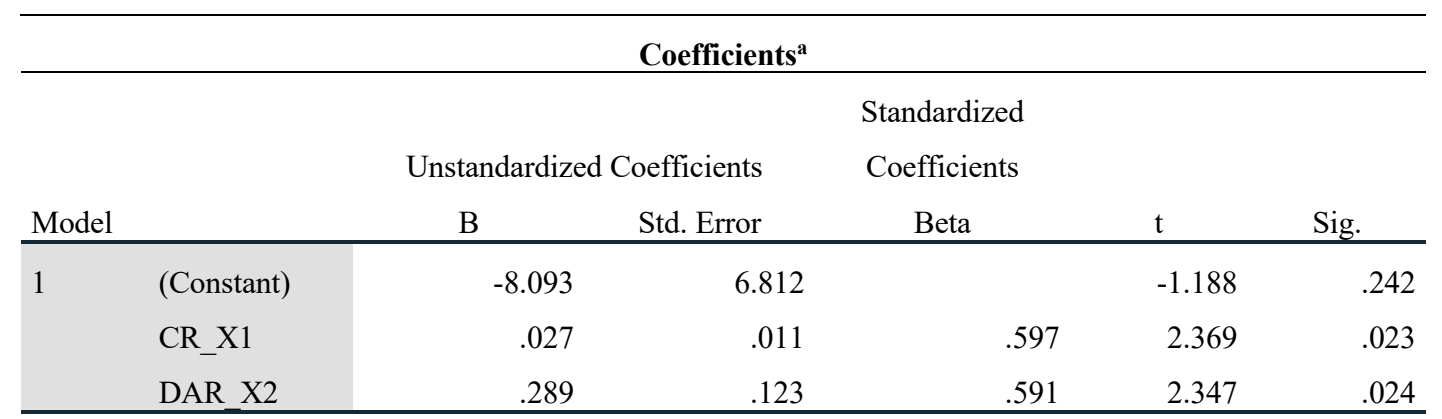

a. Dependent Variable: ROA_Y

Source: Processed Data SPSS 24, 2020

$$
\hat{\mathrm{Y}}=-8.093+0.027 \mathrm{X} 1+0.289 \mathrm{X} 2+0.379 \varepsilon
$$

From the regression function (1), it is known that:

The Current Ratio (X1), which is 0.027 and has a positive sign, indicates that the Current Ratio which measures Return on Assets (Y) has a positive and significant contribution, meaning that if the Current Ratio increases by one unit, the Return on Assets of the coal mining sub-sector will increase.

Debt to Total Asset Ratio (X2), which is 0.289 and has a positive and significant sign, indicating that the Debt to Total Asset Ratio (X2) which measures the Return on Assets of coal mining sub-sector companies has a positive and significant contribution, meaning that if the Debt to Total Assets The ratio increases by one unit, the company's Return on Assets will increase.

While $=0.379$ indicates that there are other variables not examined in this study of $37.9 \%$.

Tabel 2. Simultaneous Test

\begin{tabular}{llrrrrr}
\hline \multicolumn{7}{c}{ ANOVA $^{\mathbf{a}}$} \\
\hline Model & & Sum of Squares & df & Mean Square & \multicolumn{1}{c}{ F } & \multicolumn{1}{c}{ Sig. } \\
\hline \multirow{2}{*}{1} & Regression & 220.043 & 2 & 110.021 & 3.095 & $.057^{\text {b }}$ \\
& Residual & 1315.490 & 37 & 35.554 & & \\
& Total & 1535.533 & 39 & & & \\
\hline
\end{tabular}

a. Dependent Variable: ROA_Y 
b. Predictors: (Constant), DAR_X2, CR_X1

Source: Processed Data SPSS 24, 2020

Based on the results of statistical tests that have been carried out, it shows that the Current Ratio and Debt to Total Asset Ratio have no significant effect on Return on Assets. The absence of a significant effect of Current Ratio, and Debt to Total Asset Ratio on Return on Assets occurs because the company's current asset management is not ideal, so that some assets are still unused or idle. Because the existence of idle assets will cause fixed expenses, which will reduce the company's profit. In accordance with the theory of Horne and Machowicz [8], the ability to earn a profit is inversely proportional to the current ratio (liquidity). This inversely proportional ability will be a problem in the company when the company sets large assets but is not used optimally to obtain the level of profitability, causing the profitability of the company to decline. The company cannot fulfill the shortterm needs completely or less because the assets owned are partially used for the company's operational activities. If the company can manage current assets optimally, it is likely that the current ratio will greatly affect the company's asset returns.

Tabel 3. Partial Test

\begin{tabular}{|c|c|c|c|c|c|c|}
\hline \multicolumn{7}{|c|}{ Coefficients $^{\mathrm{a}}$} \\
\hline & & \multicolumn{5}{|c|}{ Standardized } \\
\hline & & \multicolumn{2}{|c|}{ Unstandardized Coefficients } & Coefficients & \multirow[b]{2}{*}{$\mathrm{T}$} & \multirow[b]{2}{*}{ Sig. } \\
\hline & & $\mathrm{B}$ & Std. Error & Beta & & \\
\hline \multirow[t]{3}{*}{1} & (Constant) & -8.093 & 6.812 & & -1.188 & .242 \\
\hline & CR_X1 & .027 & .011 & .597 & 2.369 & .023 \\
\hline & DAR X2 & .289 & .123 & .591 & 2.347 & .024 \\
\hline
\end{tabular}

a. Dependent Variable: ROA_Y

Source: Processed Data SPSS 24, 2020

The results of hypothesis testing indicate that the Current Ratio has a positive and significant effect on Return on Assets. This means that a large current asset value will significantly increase the company's ROA ratio. Where the company has more sources of assets that can be converted into cash originating from company profits. Components of current assets that can be converted into cash are inventory and accounts receivable which can be a source of income for the company. So that companies can maximize their profits by managing their current assets as well as possible from cash, collection of receivables and inventory. The company can benefit in the form of cash inflows into the company through the settlement of receivables so that it will increase the company's revenue.

According to Kasmir [5] Current ratio (CR) is a ratio used to measure the company's ability to pay short-term obligations or debts due immediately when paying all bills. If the current ratio is low, it can be said that the company has less capital to pay its debts. However, if the results of the high ratio measurement are not necessarily good conditions for the company. This happens because the cash is not fully utilized, which has an impact on the profits of the company.

The results of hypothesis testing illustrate that the Debt to Total Asset Ratio has a positive and significant effect on Return on Assets. As is the case with coal mining sub-sector companies where total assets are greater than debt. The total debt is small compared to the total assets so that the greater the company's income to pay off its debts to parties outside the company and shows that the total assets used for the company's operations are able to provide profits for the company.

The results of this study are in line with the theory put forward by Sudana [9] Debt to Total Asset Ratio (DAR) ratio is used to measure funds obtained from debt with the proportion of assets of financial companies. The greater this ratio, the greater the proportion of debt used in asset financing investments, so that the company's financial risk will increase, and vice versa. 


\section{Conclussion}

Based on the results of data analysis and statistical hypothesis testing in this study, the following conclusions can be drawn:

1. Current Ratio and Debt to Total Asset Ratio simultaneously have a positive and insignificant effect on Return on Assets in Coal Mining sub sector companies listed on the Indonesia Stock Exchange.

2. Current Ratio partially positive and significant effect on Return on Assets in Coal Mining subsector companies listed on the Indonesia Stock Exchange.

3. Debt to Total Asset Ratio partially positive and significant effect on Return on Assets in Coal Mining sub-sector companies listed on the Indonesia Stock Exchange.

\section{References}

[1] Kasmir, Analisis Laporan Keuangan. Jakarta: Rajawali Pers, 2015.

[2] Gunawan and M. Firza, "Pengaruh Current Ratio Dan Total Asset Turnover Terhadap Return On Asset Pada Perusahaan Plastik Dan Kemasan," J. Ris. Akunt. Aksioma, vol. 17, no. 2, pp. 136, 2018.

[3] Mahardhika and D. Marbun, "Pengaruh Current Ratio Dan Debt To Equity Ratio Terhadap Return On Assets," Widyakala J., vol. 3, p. 23, 2016.

[4] S. Akbar, N. Nurdin, and A. Azib, "Pengaruh Debt To Asset Ratio \& Debt To Equity Ratio terhadap Return On Asset (Studi pada Perusahaan Sektor Food \& Beverages yang terdaftar di Bursa Efek Indonesia)," Pros. Manaj., vol. 0, no. 0, pp. 1193-1198, 2017.

[5] Kasmir, Analisis Kinerja Keuangan. Jakarta: RajaGrafindo Persada, 2017.

[6] Irham Fahmi, Analisis Kinerja Keuangan. Bandung: Alfabeta, 2012.

[7] Sugiyono, Metode Penelitian Pendekatan Kuantitatif dan Kualitatif dan R\&D. Bandung: Alfabeta, 2015.

[8] James C Van Horne and J. M. Wachowicz, Prinsip-Prinsip Manajemen Keuangan. Jakarta: Salemba Empat, 2009.

[9] I Made Sudana, Manajemen Keuangan Perusahaan Teori dan Praktik. Jakarta: Erlangga, vol. 20, no. 5. 2014. 